\title{
Chapter 19 \\ Farmer Adaptation to Climate \\ Variability and Soil Erosion \\ in Samanalawewa Catchment in Sri \\ Lanka
}

\author{
E. P. N. Udayakumara
}

\section{Key Messages}

- Mean annual rainfall has decreased while mean annual temperature has increased from 1922 to 2008 .

- It is also observed that the general perception of the farmers is also similar in terms of the overall trend.

\subsection{Introduction}

At present, poverty is a growing concern in most of the developing and least developed countries. More than one billion people around the world live in extreme poverty. Nearly $77.4 \%$ of Sri Lanka's population live in rural areas and depend upon their local environments for their daily survival (Central Bank of Sri Lanka, 2020). Environmental degradation is a major cause of poverty among rural communities around the world. Thus, the natural resources can be considered as part and parcel of these communities and sustainable management of natural resources is very crucial for

\footnotetext{
Disclaimer: The presentation of material and details in maps used in this book does not imply the expression of any opinion whatsoever on the part of the Publisher or Author concerning the legal status of any country, area or territory or of its authorities, or concerning the delimitation of its borders. The depiction and use of boundaries, geographic names and related data shown on maps and included in lists, tables, documents, and databases in this book are not warranted to be errorfree nor do they necessarily imply official endorsement or acceptance by the Publisher, Editor(s), or Author(s).

E. P. N. Udayakumara ( $\square)$

Department of Natural Resources, Faculty of Applied Sciences, Sabaragamuwa University of Sri Lanka, Belihiloya, Sri Lanka

e-mail: udayaepn@appsc.sab.ac.lk; udayaepn@gmail.com
} 
both enhancing rural livelihoods and conserving the environment for the future (Das, 2021, Chap. 17 of this volume; Vidanage et al., 2022, Chap. 15 of this volume).

Sri Lanka is an agricultural country and nearly $25.3 \%$ of people still depend on land-centered activities for their survival (Central Bank of Sri Lanka, 2020). At present, most of the country's natural resources, viz. land, water, forest, coastal, biodiversity, air, etc., are significantly threatened. Among them, land is one of the crucial and greatly threatened natural resources in the country (Ministry of Forestry \& Environment, 2001).

From 1881 to 1900 , forest cover in Sri Lanka decreased from 85 to $70 \%$ of the total land area because central hills were cleared for plantations crops and dry zone forests were logged for timber by the British rulers. By the year 1948, when Sri Lanka got its independence, forest cover had declined to 44\% (De Zoysa, 2001), by 1981 it was 25\% (Bandarathilleke, 1991) and it further declined to only $19.9 \%$ of the country's total land area by the year 2006 (Central Bank of Sri Lanka, 2006).

Several studies (Chandrapala, 1996; Domroes, 1996) have reported that the amount of rainfall in Sri Lanka has been declining gradually. For instance, during the period 1931-1960, the average annual rainfall was estimated to be $2005 \mathrm{~mm}$. This has since declined to $1861 \mathrm{~mm}$ from 1961 to 1990 (Domroes \& Schaefer, 2000). A study of the upper catchments in the central hill country around Nuwara Eliya also indicates a declining trend in annual rainfall from 1900 to 2002 (Madduma Bandara \& Wickramagamage, 2004).

Although there are no studies on land degradation or land-use cover changes (LUCC) or on climate change impact in the Samanalawewa catchment, these phenomena are evident in the area. These changes can cause many environmental and socioeconomic problems like habitat destruction and loss of biodiversity, reduced or uneven water flows, water stresses, deterioration of water quality, the decline in agricultural production and its wealth, downstream economic damage due to sedimentation, change in the size and spatial distribution of the human population, and changes in livelihood (Technology Evaluation and Management Services, 1992a). Presently numerous drivers and forces, such as human population growth, existing land-use policies, growth of demand in agriculture, unsecured land tenure systems, infrastructure development, urbanization, destruction of forest, chena cultivation also known as shifting cultivation or swidden cultivation, soil erosion, and natural calamities pose a threat to the Samanalawewa catchment area as well as the country's natural resources.

Most developing countries have constructed dams to create small or large reservoirs to meet the demand for hydropower. However, most recent studies have argued that these artificially constructed reservoirs have provided only short-term benefits while creating other socioeconomic hardships for the local population that is dependent on agriculture (Kim, 2007).

The construction of the Samanalawewa reservoir was started in 1988 and completed in 1992 to divert the Walawe River to generate electricity. No environmental impact assessment (EIA) was undertaken while constructing the Samanalawewa reservoir, even though this was a requirement of the National Environmental (Amended) Act No. 56 of 1988, and the socioeconomic and environmental 
impacts of its early stages are not well documented. However, it is important to note that while the project had unexpected negative impacts on the traditional livelihood of people in the catchment; it also had positive effects on the region and on the national economy (Technology Evaluation and Management Services, 1992a).

Studies revealed that the Samanalawewa reservoir had impacted the livelihood of the farmers in the downstream regions while it had a relatively low impact on the upstream people. In particular, there was a deterioration of traditional paddy farming, decline of agricultural income, increasing scarcity of agricultural labor, rural-urban migration, and erosion of community cohesion due to inadequate resettlement plans for evacuees in the Samanalawewa reservoir area (Ceylon Electricity Board, 2006).

It is known that large-scale reservoirs constructed for irrigation and hydropower developments not only have socioeconomic impacts but also create lasting environmental damages including changes in the weather patterns (Rosenberg et al., 1995). People in developing countries are the most vulnerable to climate variability impacts because they are more exposed to weather extremes without the ability to safeguard themselves and because of low adaptive capacity to climate variability (Tol et al., 2004).

The Samanalawewa reservoir diverted the waterways, removed hundreds of hectares of land from the landscape, caused loss of natural high forest cover $(\leq$ $430 \mathrm{~m}$ ), led to extensive agricultural expansion on eroded lands, caused land salinity, and loss of habitat (Central Engineering Consultancy Bureau, 1991). In addition, as the reservoir was being filled in 1992 a major leak $\left(7.5 \mathrm{~m}^{3} \mathrm{~s}^{-1}\right)$ caused a landslide approximately $300 \mathrm{~m}$ downstream of the dam. To control that leak, the "Wet Blanketing" method was used. There is still a leak which is about $1.8 \mathrm{~m}^{3} \mathrm{~s}^{-1}$ (Laksiri et al., 2005).

Several reports and studies suggest that climate variability, LUCC and land degradation are taking place in Samanalawewa catchment as well as other catchments in Sri Lanka at present (Udayakumara et al., 2010). However, there is a dearth of adequate and reliable information and understanding related to climate variability and land degradation due to soil erosion which limits our ability to monitor, mitigate and also develop appropriate policies for the long-term sustainability of the catchment area. Therefore, this study tries to assess the status of climate variability, land degradation and farmers' adaptation of soil and water conservation (SWC) measures in the study area so that options for better management of catchment resources can be developed in the future.

\subsection{Study Area and Methods}

\subsubsection{Study Area}

The Samanalawewa catchment is one of the most important catchments in the country because of its diverse land uses. The study area is situated in the Ratnapura District 


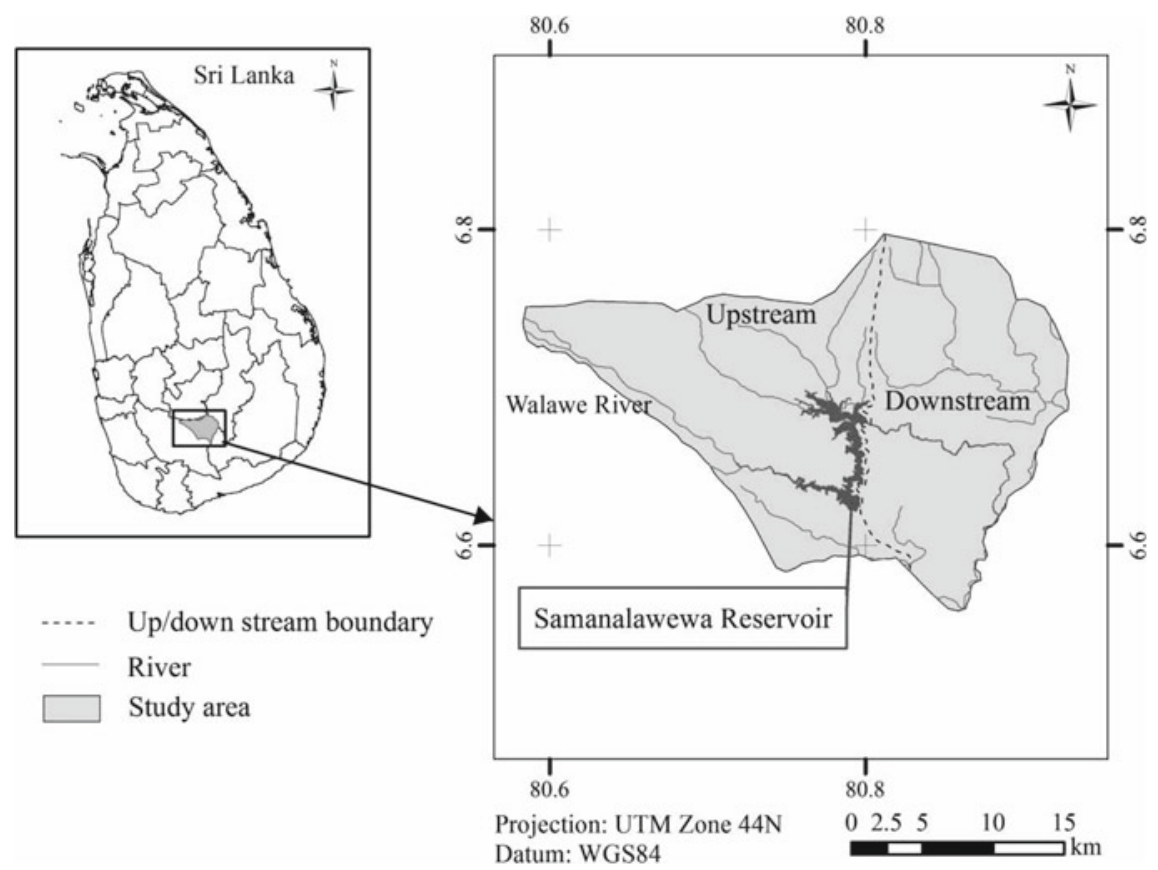

Fig. 19.1 Location map of the study area. Source Udayakumara et al. (2012)

of Sri Lanka, stretching between $80.58^{\circ}$ and $80.92^{\circ}$ east longitude and $6.56^{\circ}$ to $6.80^{\circ}$ north latitude covering an area of about $536 \mathrm{~km}^{2}$ (Fig. 19.1). The upper part of the Samanalawewa catchment is situated on the southern face of the rise to Horton Plains and Peak Wilderness sanctuary in the Nuwara-Eliya Divisional Secretariat Division (DSD) of the Nuwara-Eliya District, while the lower part inclusive of the Samanalawewa reservoir (897 ha) lies within the DSD of Imbulpe and Balangoda.

The region is mainly drained by the Walawe River and its tributaries, such as Belihul Oya (Tributary), Denagan Oya, Diyawini Oya, Kuda Oya, and Hulanda Oya. During 1987-1992, Walawe River was dammed at the confluence of the Belihul Oya and the Walawe River leading to the formation of the Samanalawewa reservoir extending over 897 ha surface area. The Samanalawewa reservoir generates 60$120 \mathrm{MW}$ of hydropower and is the main man-made water body in the catchment (Technology Evaluation and Management Services, 1992b). This single-purpose (only hydropower) project (Technology Evaluation and Management Services, 1992a) has caused changes to the ecosystem though water diversion and is one of the important factors behind the socioeconomic and associated environmental impacts in the catchment through. The population of 114,743 in the catchment area (Department of Census \& Statistics Sri Lanka, 2008) is not evenly distributed because of terrain and variation in land conditions.

Climatically the catchment belongs to the three zones, viz. the wet (rainfall over $2500 \mathrm{~mm}$ ), intermediate (1750-2500 $\mathrm{mm}$ ), and the dry (below $1750 \mathrm{~mm}$ ). The upper 
catchment (upstream or upper area of the catchment from the dam) is in the wet zone while the lower catchment area is in the intermediate zone. Geographically, the region consists of rocks belonging to the Highland group, comprising quartzite, marbles, and undifferentiated metasediment such as garnet, granulite, charnockite, and biotic gneisses (Technology Evaluation and Management Services, 1992a).

\subsubsection{Types and Sources of Data}

This section briefly explains the types and sources of data used in this research study. Data was collected from a variety of sources in the form of tabular data, reports, and field surveys. The basic data used in the study is presented in Table 19.1.

The study area consists of 23,304 households (HHs) in 67 upstream villages and 4638 HHs in 9 downstream villages (Department of Census \& Statistics Sri Lanka,

Table 19.1 Data types and sources

\begin{tabular}{|c|c|c|}
\hline Data & Data type & Source \\
\hline Soil & $\begin{array}{l}\text { - Minimum and the maximum } \\
\text { soil erosion rates }\left(\mathrm{mm} \mathrm{yr}^{-1}\right) \\
\text { at } 30^{\circ} \text { slopes from January to } \\
\text { December } 2008 \text { and } \\
\text { - Bulk density }\end{array}$ & Field experiments \\
\hline \multirow[t]{2}{*}{ RS } & $\begin{array}{l}\text { - ALOS image (sensor: } \\
\text { AVNIR-2, scene ID: } \\
\text { ALAV2A111173460, } \\
\text { resolution: } 12 \text { m spatial, } \\
\text { acquisition date: February } \\
\text { 25, 2008) }\end{array}$ & $\begin{array}{l}\text { Geoinformatics Centre, AIT, } \\
\text { Thailand }\end{array}$ \\
\hline & $\begin{array}{l}\text { - ALOS image (sensor: } \\
\text { AVNIR-2, scene ID: } \\
\text { ALAV2A111173470, } \\
\text { resolution: } 12 \text { m spatial, } \\
\text { acquisition date: February } \\
\text { 25, 2008) }\end{array}$ & $\begin{array}{l}\text { Geoinformatics Centre, AIT, } \\
\text { Thailand }\end{array}$ \\
\hline GIS & $\begin{array}{l}\text { - Digital elevation data (scale } \\
1: 10,000)\end{array}$ & $\begin{array}{l}\text { Department of Survey, Sri } \\
\text { Lanka }\end{array}$ \\
\hline Meteorological & $\begin{array}{l}\text { - Yearly rainfall from } 1922 \text { to } \\
2008 \text { and Temperature from } \\
1973 \text { to } 2008\end{array}$ & $\begin{array}{l}\text { Department of Meteorology, } \\
\text { Sri Lanka and Weather Stations } \\
\text { of the study area }\end{array}$ \\
\hline Socioeconomic & $\begin{array}{l}\text { - HH and livelihood-related } \\
\text { information from } 1986 \text { to } \\
2008\end{array}$ & Field survey \\
\hline Other published/unpublished & - & $\begin{array}{l}\text { Various publications, } \\
\text { documents, reports, etc. }\end{array}$ \\
\hline
\end{tabular}

Source Udayakumara (2011) 
2007; Udayakumara et al., 2012). For this study, 15 villages were selected randomly from upstream and 6 villages from downstream. The total number of HHs in the 21 selected villages was 7269 . For this study, 201 households were sampled from the watershed.

The sampled $201 \mathrm{HHs}$ were interviewed from February to June 2009. A pretested structured questionnaire was used to ascertain information on socioeconomic conditions, farmer's perceptions of the climate variability of the area. The interviews were conducted with the help of five trained field enumerators.

\subsubsection{Research Methods}

\subsubsection{Assessing Climate Variability}

Average annual rainfall and temperature data were collected from nine locations established in the study area (Fig. 19.2) namely Agarsland Estate, Balangoda Estate, Non-Pareil Estate, Rye Estate, Sabaragamuwa University of Sri Lankan, Samanalawewa Dam Site Office, Irrigation Office-Kaltota, Agriculture In-service Training Institute-Rajawaka and Balangoda Post Office. Farmer's perceptions on climate variability data such as rainfall (amount, intensity, and duration/storm event), temperature (daytime temperature, nighttime temperature, number of daytime hot

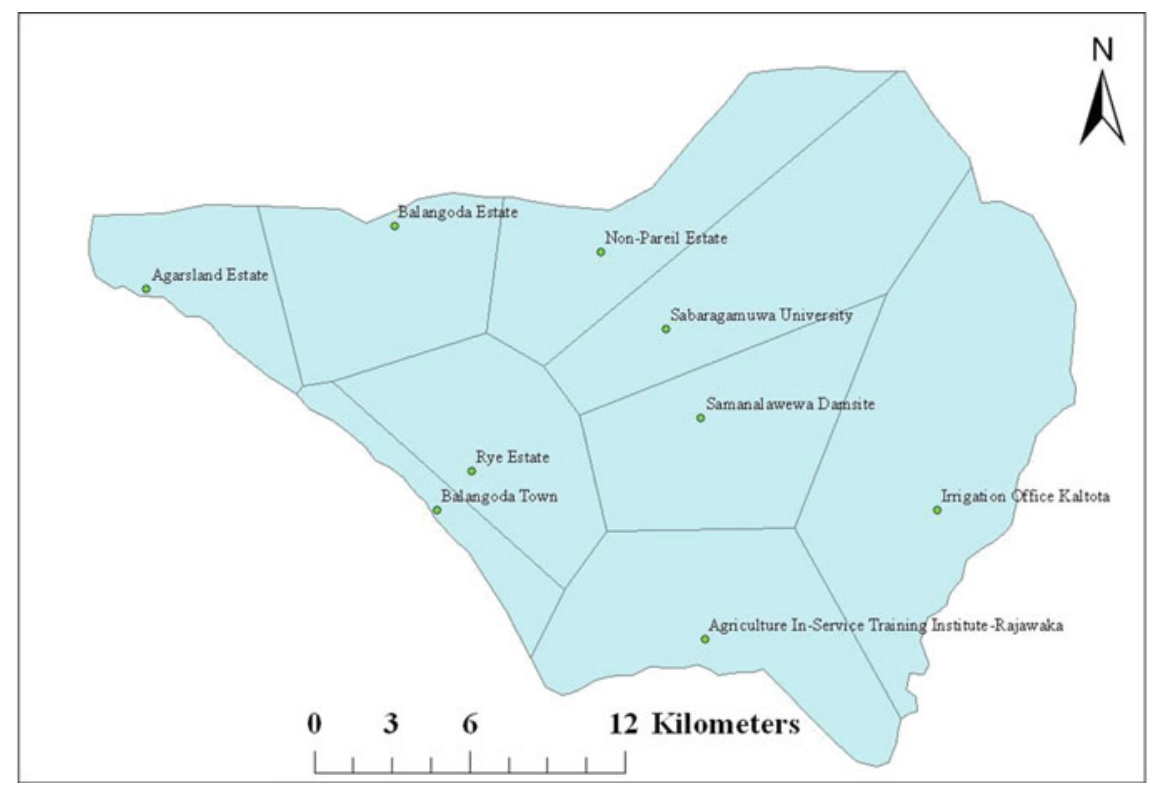

Fig. 19.2 Distribution of weather stations in the study area and their Thiessen Polygons. Source Udayakumara (2011) 
days, and number of nighttime hot days) were collected through a survey. The data was analyzed using SPSS ${ }^{\text {TM }} 16$ and MINITAB ${ }^{\text {TM }} 14$ statistical software.

To find out the best-fitted rainfall and temperature models, trend analysis was carried out using three types of time series trend models such as linear, exponential growth, and quadratic. Then considering each model's accuracy measures (mean absolute percentage error or MAPE, mean absolute deviation or MAD, and mean squared deviation or MSD), the best-fitted rainfall model and temperature models (minimum, maximum, and average annual) were selected. Finally, based on questionnaire survey data, farmer's perception on climate variability from 1997 to 2008 was analyzed.

\subsubsection{Assessing Soil Erosion}

Due to lack of availability of soil erosion assessment-related data, it was limited to use the data-intensive soil erosion models for the study area. Thus, the empirical soil erosion model developed by Honda (1993) was used to assess the annual rate of soil erosion in the study area (Udayakumara et al., 2010). The model has given satisfactory results in other areas with similar climatic and/or geomorphologic conditions to this study area (Udayakumara, 2011), like the Ashio region of Japan (Honda, 1993), the Siwaliks in Nepal (Honda et al., 1996), and the mountainous area of Northern Thailand (Hazarika \& Honda, 2001). The strength of the model is that it is not data-intensive and can be used in an area like the Samanalawewa catchment, where data is scarce (Udayakumara et al., 2010).). In terms of model performance, Honda et al. (1996) reported that this model has produced results similar in quality to that produced by extensive fieldwork. The model is mainly governed by slope gradient, vegetation index, and maximum and minimum rates of soil erosion at $30^{\circ}$ slopes (Udayakumara, 2011).

\subsubsection{Assessing Farmers' Adaptation of SWC Measures}

As farmers experience soil erosion in the catchment area, they might resort to several different types of soil and water conservation (SWC) measures (Udayakumara et al., 2012). In this study, the adoption of SWC measures was a dichotomous-dependent variable $(Y)$ that signifies whether or not a household is willing to adopt SWC measures. $Y=1$, if a $\mathrm{HH}$ is willing to adopt SWC measures, and $Y=0$ otherwise. The selected 15 explanatory variables that are hypothesized to have an association with the willingness to adopt SWC measures were used in the study to explain their decisions. The findings of the past studies and questionnaire surveys and existing theories were used to select the 15 explanatory variables and structure the working hypotheses (Udayakumara et al., 2012). The potential explanatory variables, which are hypothesized to influence farmers' willingness to adopt SWC measures in the study area, are farmers' perception of soil erosion problem, household head's age, education, and gender; security of land tenure, past experiences, land size, off-farm 
income, training on SWC, and advice from extension officers. A logistic regression model was used to the set of explanatory variables mentioned above where the dependent variable (adoption of SWC measure) is binary.

\subsection{Results and Discussion}

This section presents the results and discussion of climate variability, land degradation due to soil erosion and farmers' adaptation of SWC measures.

\subsubsection{Rainfall Variability}

The respective values of mean, minimum, maximum, and range for average annual rainfall during the period of 1922-2008 were found to be 2247.7 ( $\mathrm{SD}=565.8$ ), $612.3,3500.0$, and 2887.7 in $\mathrm{mm}$. The maximum and minimum rainfall amounts were in the years 1922 and 1981, respectively. The obtained standard deviation value (SD) for the average annual rainfall is quite high, which implies that rainfall variation is fairly high within the considered period.

The trend analysis yielded three rainfall models, viz. linear, exponential growth, and quadratic for the average annual rainfall. Considering these three models accuracy measures (MAPE, MAD and MSD), a model with the least MAPE, MAD, and MSD values was selected as the best rainfall model for the study area. According to the above three models, the linear trend model has the least values of MAPE, MAD, and MSD, compared to the other two models. Results suggest that the average annual rainfall of the area has decreased by $5.5 \mathrm{~mm}$ per year from 1922 to 2008 (Fig. 19.3). Deforestation, agricultural expansion, and development of infrastructure in the study area are mainly attributed to the reduction in rainfall (Technology Evaluation and Management Services, 1992a). According to the previous literature, Chandrapala (1996) has disclosed that the average annual rainfall over Sri Lanka has also decreased $4.8 \mathrm{~mm}$ per year from 1961 to 1990 . Based on the estimates, the forecasted average annual rainfall value in the year 2030 would be $1893.5 \mathrm{~mm}$.

According to Table 19.2 for the period from 1997 to $2008,77 \%$ of respondents said the amount of rainfall had decreased while $13 \%$ felt there was no change, and $10 \%$ said it had increased. $65 \%$ of respondents said the intensity of rainfall had decreased followed by $23 \%$ who said there was no change, while $12 \%$ claimed it had increased. Duration of rainfall is also considered to have decreased by $67 \%$ of respondents, followed by $18 \%$ who reported no change and $15 \%$ reporting an increase (Table 19.2). 


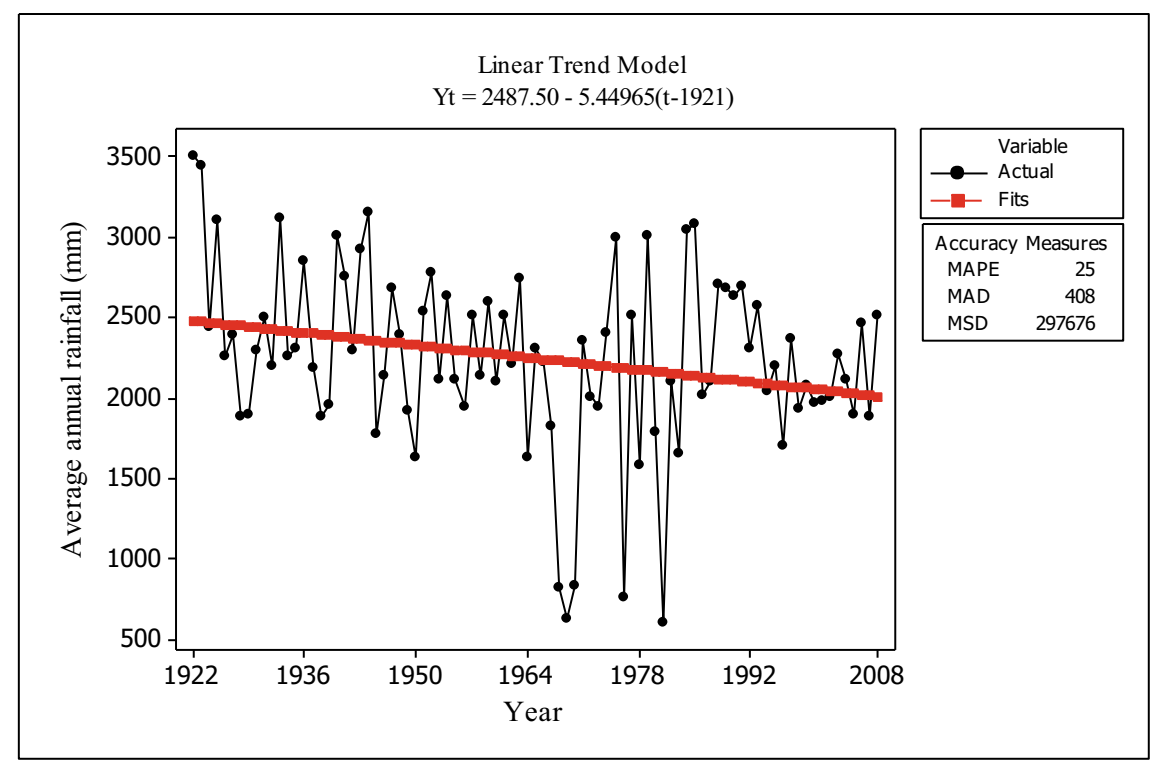

Fig. 19.3 Trend analysis plot for average annual rainfall (1922-2008). Source Udayakumara (2011)

Table 19.2 Perceived rainfall changes from people (1997-2008)

\begin{tabular}{l|l|l|l}
\hline \multirow{2}{*}{ Perception on rainfall } & Decreased & Increased & No change \\
\cline { 2 - 4 } & \multicolumn{2}{|l}{$\%$ Respondents } & 13 \\
\hline Amount & 77 & 10 & 23 \\
\hline Intensity & 65 & 12 & 18 \\
\hline Duration (storm event) & 67 & 15 & \\
\hline
\end{tabular}

Source Udayakumara (2011)

\subsubsection{Temperature Variability}

The respective values of mean, minimum, maximum, and range for average annual minimum temperature were found to be $19.6(\mathrm{SD}=0.7), 18.1,21.0$, and $2.9 \mathrm{in}{ }^{\circ} \mathrm{C}$. The trend analysis yielded three average annual minimum temperature models, viz. linear, exponential growth, and quadratic. According to these three models, the exponential growth model has the least values of MAPE, MAD, and MSD, compared to the other two models. Thus, the best-fitted average annual minimum temperature model for the study area is an exponential growth model shown in Fig. 19.4. The model shows that the average annual minimum temperature of the study area has increased from 1973 to 2008 . Thus, the forecasted average annual minimum temperature value in 2030 would be $20.8^{\circ} \mathrm{C}$. 


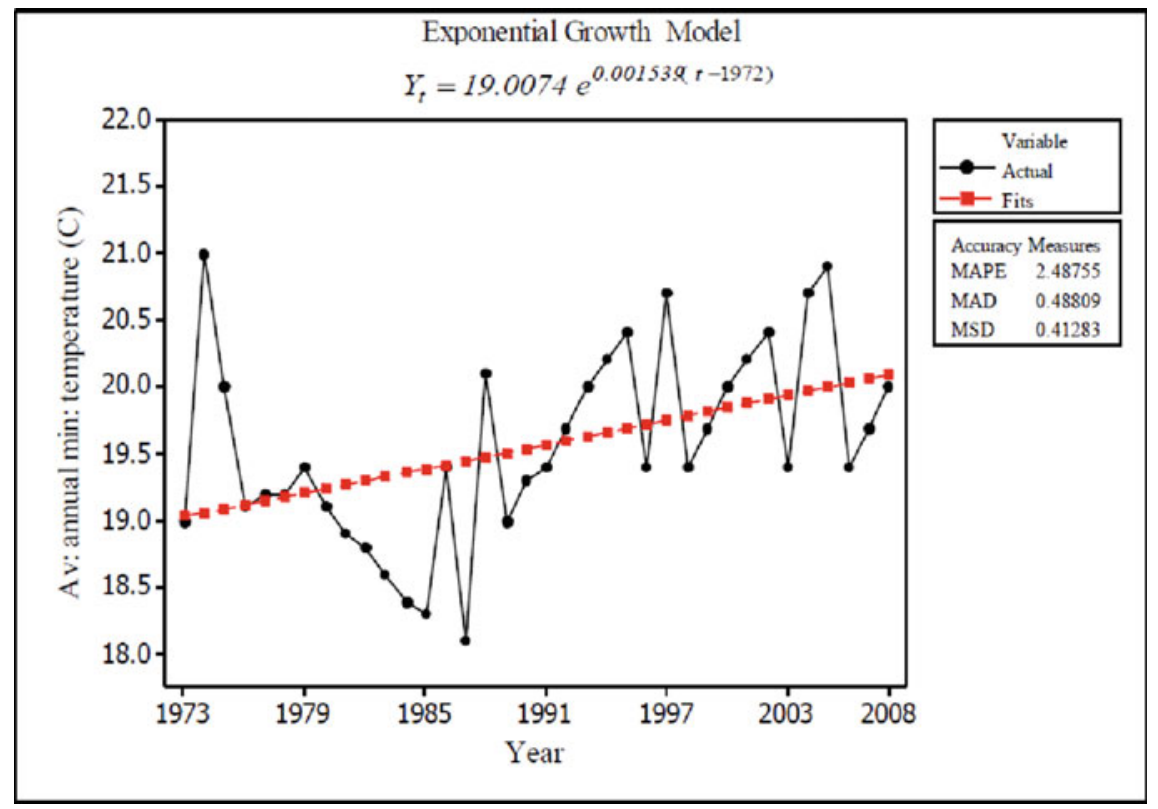

Fig. 19.4 Trend analysis plot for average annual minimum temperature (1973-2008). Source Udayakumara (2011)

For the average annual maximum temperature, mean, minimum, maximum, and range were found to be $27.67(\mathrm{SD}=0.40), 26.8,28.6$, and $1.8 \mathrm{in}{ }^{\circ} \mathrm{C}$, respectively. The trend analysis yielded three average annual maximum temperature models, viz. linear, exponential growth, and quadratic. According to these three models, the linear trend model has the least values of MAPE, MAD, and MSD, compared to the other two models. Thus, the best-fitted average annual maximum temperature model for the study area is a linear trend model (Udayakumara, 2011) as shown in Fig. 19.5.

The model shows that the average annual maximum temperature of the study area has increased from 1973 to 2008 . As the rate of temperature increment is about + $0.02{ }^{\circ} \mathrm{C} \mathrm{yr}^{1}{ }^{1}$, the forecasted average annual maximum temperature value in 2030 would be $28.3^{\circ} \mathrm{C}$ (Udayakumara, 2011).

While the respective values of mean, minimum, maximum, and range for average annual temperature were found to be $23.6(\mathrm{SD}=0.4), 22.8,24.5$, and 1.7 in ${ }^{\circ} \mathrm{C}$, the trend analysis yielded three average annual temperature models: linear, exponential growth, and quadratic. According to these three models, the linear trend model has the least values of MAPE, MAD, and MSD, compared to the other two models. Thus, the best-fitted average annual temperature model for the study area is a linear trend model (Udayakumara, 2011) as shown in Fig. 19.6 as the rate of temperature

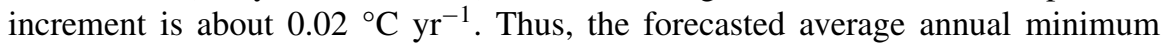
temperature value for the year 2030 would be $24.5^{\circ} \mathrm{C}$. In general, the global average temperature is projected to rise in the range of $1.4-5.8^{\circ} \mathrm{C}$ by the year 2100 under the 


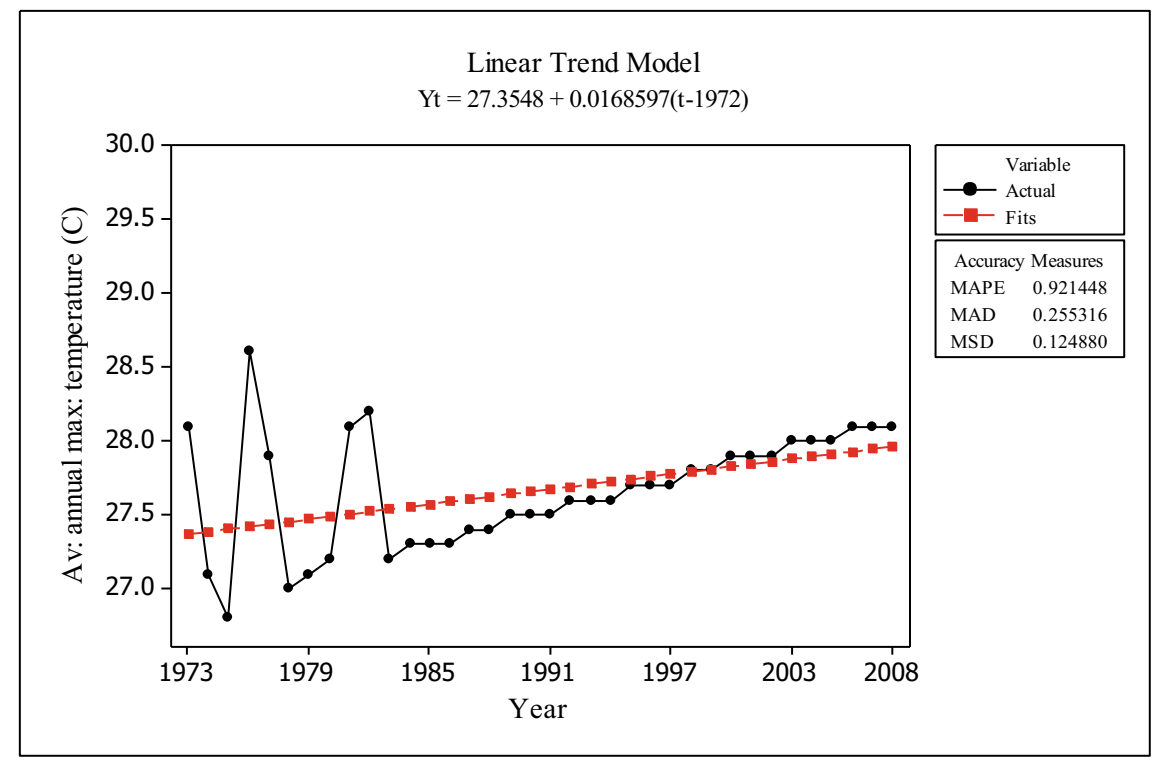

Fig. 19.5 Trend analysis plot for average annual maximum temperature (1973-2008). Source Udayakumara (2011)

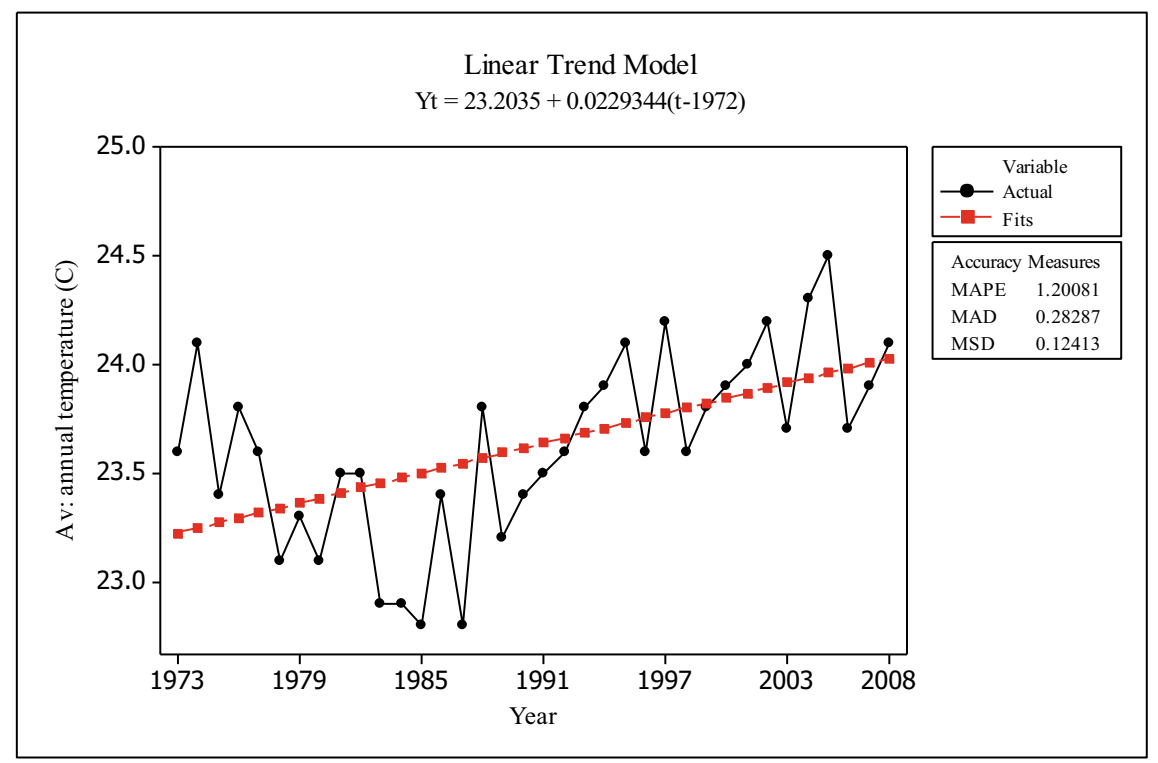

Fig. 19.6 Trend analysis plot for average annual temperature (1973-2008). Source Udayakumara (2011) 
Table 19.3 Perceived temperature changes from people (1997-2008)

\begin{tabular}{l|l|l|l}
\hline \multirow{2}{*}{$\begin{array}{l}\text { Perception on } \\
\text { temperature }\end{array}$} & Decreased & Increased & No change \\
\cline { 2 - 4 } & \% Respondents & \multicolumn{2}{l}{} \\
\hline $\begin{array}{l}\text { Daytime } \\
\text { temperature }\end{array}$ & 5 & 72 & 23 \\
\hline $\begin{array}{l}\text { Nighttime } \\
\text { temperature }\end{array}$ & 7 & 66 & 27 \\
\hline $\begin{array}{l}\text { Number of daytime } \\
\text { hot days }\end{array}$ & 2 & 81 & 17 \\
\hline $\begin{array}{l}\text { Number of } \\
\text { nighttime hot days }\end{array}$ & 23 & 63 & 14 \\
\hline
\end{tabular}

Source Udayakumara (2011)

different emission scenarios (Intergovernmental Panel on Climate Change, 1995). However, according to this study, in this area, this value would also be within the IPCC range, i.e., about $2.1^{\circ} \mathrm{C}$ (Intergovernmental Panel on Climate Change, 1995). This is a sign of global warming.

According to Table 19.3 and as shown by $72 \%$ of respondents, the daytime temperature increased during the period from 1997 to 2008 , followed by $23 \%$ who said there was no change and $5 \%$ reporting a decrease. About $66 \%$ of respondents, nighttime temperature was received to have increased followed by $27 \%$ saying there was no change and $7 \%$ reporting a decrease. As per the perception of the respondents, the number of daytime hot days increased by $81 \%$, which is followed by $17 \%$ of no change and $2 \%$ perceived it to have decreased. According to $63 \%$ of respondents, the number of nighttime hot days has also increased whereas $23 \%$ thought it has decreased and $14 \%$ said there was no change.

According to the weather stations' temperature analysis results, the temperature has actually increased which is similar to the perception of the majority of people. Clearly, they have noticed the changes in the number of daytime and nighttime hot days in the area.

\subsubsection{Soil Erosion}

Maximum, minimum, and mean annual soil erosion rates were $22.1 \mathrm{~mm} \mathrm{yr}^{-1}$, $0.0 \mathrm{~mm} \mathrm{yr}^{-1}$, and $0.33 \mathrm{~mm} \mathrm{yr}^{-1}(\mathrm{SD}=0.31)$, respectively. Based on soil erosion calculated at each pixel, six preliminary categories of soil erosion ranging from very low to extremely high were identified (Table 19.4). The study area's gross rate of soil erosion ranged from 0.0 to $289.0 \mathrm{tha}^{-1} \mathrm{yr}^{-1}$ with an average rate of $4.3 \mathrm{tha}^{-1}$ $\mathrm{ya}^{-1}(\mathrm{SD}=4.1)$ (Fig. 19.7).

Furthermore, $65 \%$ of the surveyed people perceived soil erosion that had decreased followed by $30 \%$ who said it had increased and only $5 \%$ reported no change. Most 
Table 19.4 Status of soil erosion in the study area, 2008

\begin{tabular}{l|l|l}
\hline Soil erosion status & Range $\left(\mathrm{t} \mathrm{ha}^{-1} \mathrm{yr}^{-1}\right)$ & $\%$ area \\
\hline Very low & $0-4$ & 55.3 \\
\hline Low & $4-8$ & 30.2 \\
\hline Moderately high & $8-12$ & 10.1 \\
\hline High & $12-16$ & 2.9 \\
\hline Very high & $16-20$ & 0.9 \\
\hline Extremely high & $20-289$ & 0.6 \\
\hline
\end{tabular}

Source Udayakumara (2011) Note Total area $\left(536 \mathrm{~km}^{2}\right)$

Fig. 19.7 Soil erosion map of the study area. Source Udayakumara (2011)

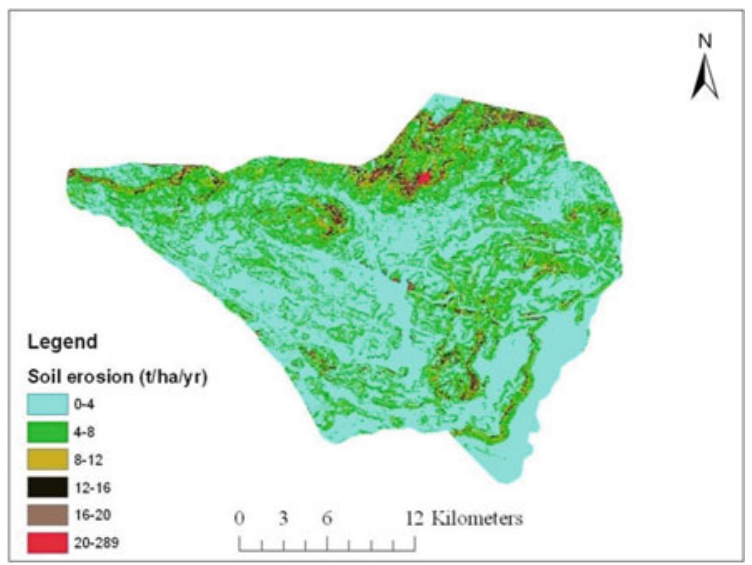

believe that the main reason for this decline in erosion and landslides is due to the decline of rainfall.

\subsubsection{Farmers' Adoption of SWC Measures}

Out of the 201 sample respondents, $121(60.2 \%)$ were found to be willing to adopt the SWC measures, whereas the remaining 80 (39.8\%) respondents were not willing to adopt those conservation measures. The adopted SWC measures include agronomics (e.g., the use of mulch and organic manure, soil surface/subsurface treatments), vegetative (e.g., increasing trees, shrub, and grass cover), structural (e.g., constructing terraces, bunds, and ditches), and management (e.g., changing species composition of crops, controlling cropping intensity, and observing fallow period).

Moreover, the results also indicated that $19.8 \%$ of the farmers have been adopting SWC measures for more than 20 years, with $12.4 \%$ of farmers adopting the measures 
Table 19.5 Impacts of adopted SWC measures

\begin{tabular}{l|l|l|l|l}
\hline $\begin{array}{l}\text { Adoption of } \\
\text { SWC measures } \\
\text { years) }\end{array}$ & $\%(n)$ & $\begin{array}{l}\text { Average SWC } \\
\text { cost USD ha } \\
\mathrm{yr}^{-1}\end{array}$ & $\begin{array}{l}\text { Average rate of soil } \\
\text { erosion } \mathrm{tha}^{-1} \mathrm{yr}^{-1}(\mathrm{SD})\end{array}$ & $\begin{array}{l}\text { Soil erosion versus } \\
\text { soil generation }\end{array}$ \\
\hline$<5$ & $24.8(30)$ & 85.5 & $10.5(5.7)$ & 48 \\
\hline $5-10$ & $18.2(22)$ & 75.5 & $7.8(5.2)$ & 35 \\
\hline $10-15$ & $24.8(30)$ & 66.5 & $3.5(0.8)$ & 16 \\
\hline $15-20$ & $12.4(15)$ & 45.7 & $2.5(0.7)$ & 11 \\
\hline$>20$ & $19.8(24)$ & 30.8 & $1.8(0.5)$ & 8 \\
\hline
\end{tabular}

Source Udayakumara (2011)

Note $n$ Number of HHs according to years of SWC measures adopted, UD\$ US dollar, SD Standard deviation

for $15-20$ years, $24.8 \%$ for $10-15$ years, $18.2 \%$ for 5-10 years, and another $24.8 \%$ for less than 5 years (Table 19.5).

Since the farmers in the study area have been adopting the SWC measures, the average SWC costs, the average rate of soil erosion, and the ratios of soil erosion vs. natural soil generation have declined drastically. Table 19.5 shows that the farmers who have adopted the SWC measures for more than 20 years incurred the least conser-

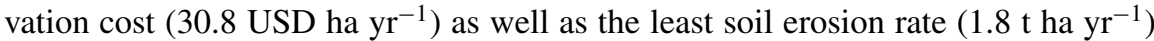
compared with the farmers who have adopted SWC measures only recently (less than 5 years).

Finally, out of the thirteen correlated variables in the binary logistic model, the following six variables are included in the binary logistic model: four variables, viz. farmer's perception of soil erosion problem, gender of the $\mathrm{HH}$ head, training on SWC, and advice from the extension officers are significant at $0.01 \%$; the other two variables such as past awareness about technology and off-farm income are significant at $0.05 \%$.

\subsection{Conclusions}

Average annual rainfall anomalies have shown a significant decreasing trend from 1922 to 2008 in the study area. The rate of decrease of average annual rainfall for the above period was in the order of $5.5 \mathrm{~mm}$ per year. It is also observed that the general perception of the farmers is also similar in terms of the overall trend. Average annual minimum, average annual maximum, and average temperatures have shown significant increasing trends from 1973 to 2008. This is also similar in terms of the farmer's perception of temperature. The results indicate that the general perception is in line with the trends in the scientific data. The facts and the experiences coincide, and as a consequence of this situation, at present dwellers of the catchment encounter many negative impacts such as scarcity of water for agriculture, loss of biodiversity, and unexpected droughts and rains. 
According to the Kyoto Protocol, the climate change issue is a global problem, and therefore, it needs the cooperation of all countries. Thus, to arrest the decrease of average annual rainfall and increment of average temperature in Sri Lanka, proper programs/policies have to be worked out. Among them, implementation of reforestation and afforestation programs for carbon sequestration, prevention of deforestation, formulation of policies to curtail unnecessary gas emissions, reduction of the use of fossil fuel by improving the efficiency of energy usage and by substituting renewable energy resources are very important.

Soil erosion is also a serious concern in most parts of Sri Lanka. In the Samanalawewa catchment, the rate of soil erosion ranges from 0 to $289 \mathrm{t} \mathrm{ha}^{-1} \mathrm{yr}^{-1}$ with a catchment level average of $4.3 \mathrm{tha}^{-1} \mathrm{yr}^{-1}$. The household survey reveals that inappropriate soil and crop management practices and increased economic activities due to population growth, poverty, and inadequate labor are the major indirect causes of soil erosion.

As soil erosion is one of the prominent types of land degradation in the study area at present, adoption of new and improved soil conservation measures by farmers has significant effects on soil productivity on-site as well as downstream. According to the survey, $60.2 \%$ were found to be willing to adopt the improved SWC measures. The study found that farmers' perception of soil erosion as a problem, gender of the head of the household, level of awareness about soil conservation technology, off-farm income, training on SWC measures, and regular advice from extension officers are major determinants of adoption of improved SWC measures by the farmers. Finally, the farmers who have adopted the SWC measures incurred the least conservation cost as well as the least soil erosion rate in their lands compared with the farmers who have adopted SWC measures only recently.

\section{References}

Bandarathilleke, H. M. (1991). National forest policy strategies for conservation of forest resources of Sri Lanka. Paper presented at the Proceedings of the Second Regional Workshop on Multiple Trees, Kandy, Sri Lanka.

Central Bank of Sri Lanka. (2006). Annual report, 2006. Central Bank of Sri Lanka.

Central Bank of Sri Lanka. (2020). Sri Lanka socio-economic data 2020. Statistics Department, Central Bank of Sri Lanka.

Central Engineering Consultancy Bureau. (1991). Samanalawewa hydro electric project environment study (Final Report) (p. 159).

Ceylon Electricity Board. (2006). Long term generation expansion planning studies 2006-2015. Transmission and Generation Planning Branch, Ceylon Electricity Board.

Chandrapala, L. (1996). Long term trends of rainfall and temperature in Sri Lanka. Climate Variability and Agriculture, 153-162.

Das, S. (2021). Valuing the role of mangroves in storm damage reduction in coastal areas of Odisha. In A. K. E. Haque, P. Mukhopadhyay, M. Nepal, \& M. R. Shammin (Eds.), Climate change and community resilience: Insights from South Asia. Springer.

De Zoysa, M. (2001). A review of forest policy trends in Sri Lanka. Policy Trend Report, 2001, 57-68. 
Department of Census and Statistics Sri Lanka. (2007). Handbook of census and statics-2007. Department of Census and Statistics.

Department of Census and Statistics Sri Lanka. (2008). Handbook of census and statics-2008. Department of Census and Statistics.

Domroes, M. (1996). Rainfall variability over Sri Lanka. Climate Variability and Agriculture, 163179.

Domroes, M., \& Schaefer, D. (2000). Trends of recent temperature and rainfall changes in Sri Lanka. Paper presented at the Proceedings of the International Conference on Climate Change and Variability.

Hazarika, M., \& Honda, K. (2001). Estimation of soil erosion using remote sensing and GIS, its valuation and economic implications on agricultural production economic implications on agricultural production. Paper presented at the Sustaining the Global Farm 10th International Soil Conservation Organization Meeting Purdue University and the USDA-ARS National Soil Erosion Research Laboratory, USA.

Honda, K. (1993). Evaluation of vegetation change in the Ashio Copper Mine using remote sensing and its application to forest conservation works ( $\mathrm{PhD}$ thesis). University of Tokyo.

Honda, K., Samarakoon, L., Ishibashi, A., Mabuchi, Y., \& Miyajima, S. (1996). Remote sensing and GIS technologies for denudation estimation in a Siwalik watershed of Nepal.

Intergovernmental Panel on Climate Change. (1995). The regional impacts of climate change: An assessment of vulnerability: Cambridge University Press.

Kim, S. (2007). Evaluation of negative environmental impacts of electricity generation: Neoclassical and institutional approaches. Energy Policy, 35(1), 413-423.

Laksiri, K., Gunathilake, J., \& Iwao, Y. (2005). A case study of the Samanalawewa Reservoir on the Walawe river in an area of Karst in Sri Lanka.

Madduma Bandara, C. M., \& Wickramagamage, P. (2004). Climate change and its impact on upper watershed of the hill country of Sri Lanka. Climate Change Secretariat Working Paper. Environmental Economics and Global Affairs Division, Ministry of Environment and Natural Resources.

Ministry of Forestry and Environment. (2001). Sri Lanka: State of the Environment in 2001. Department of Government Printing.

Rosenberg, D. M., Bodaly, R. A., \& Usher, P. J. (1995). Environmental and social impacts of large scale hydroelectric development: Who is listening? Global Environmental Change, 5(2), $127-148$.

Technology Evaluation and Management Services. (1992a). Samanalawewa hydro electric project. Environmental Post Evaluation Study (Interim Report) (p. 15).

Technology Evaluation and Management Services. (1992b). Samanalawewa hydro electric project. Environmental post evaluation study (Draft Final Report) (p. 250).

Tol, R. S. J., Downing, T. E., Kuik, O. J., \& Smith, J. B. (2004). Distributional aspects of climate change impacts. Global Environmental Change Part A, 14(3), 259-272.

Udayakumara, E. P. N. (2011). Land degradation and rural livelihood in the Samanalawewa catchment, Sri Lanka $(\mathrm{PhD})$. Asian Institute of Technology, School of Environment, Resources and Development, Thailand, Asian Institute of Technology, School of Environment, Resources and Development.

Udayakumara, E. P. N., Shrestha, R. P., Samarakoon, L., \& Schmidt-Vogt, D. (2010). People's perception and socioeconomic determinants of soil erosion: A case study of Samanalawewa watershed, Sri Lanka. International Journal of Sediment Research, 25(4), 323-339.

Udayakumara, E. P. N., Shrestha, R., Samarakoon, L., \& Schmidt-Vogt, D. (2012). Mitigating soil erosion through farm-level adoption of soil and water conservation measures in Samanalawewa Watershed, Sri Lanka. Acta Agriculturae Scandinavica, Section B-Soil \& Plant Science, 62(3), 273-285. 
Vidanage, S.P., Kotagama, H.b., \& Dunusinghe, P. (2022). Sri Lanka's small tank cascade systems: building agricultural resilience in the dry zone. In A. K. E. Haque, P. Mukhopadhyay, M. Nepal, \& M. R. Shammin (Eds.), Climate change and community resilience: Insights from South Asia. Springer.

Open Access This chapter is licensed under the terms of the Creative Commons AttributionNonCommercial-NoDerivatives 4.0 International License (http://creativecommons.org/licenses/bync-nd/4.0/), which permits any noncommercial use, sharing, distribution and reproduction in any medium or format, as long as you give appropriate credit to the original author(s) and the source, provide a link to the Creative Commons licence and indicate if you modified the licensed material. You do not have permission under this licence to share adapted material derived from this chapter or parts of it.

The images or other third party material in this chapter are included in the chapter's Creative Commons licence, unless indicated otherwise in a credit line to the material. If material is not included in the chapter's Creative Commons licence and your intended use is not permitted by statutory regulation or exceeds the permitted use, you will need to obtain permission directly from the copyright holder.

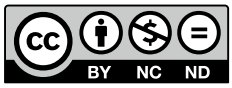

